\section{VALERII PETROVICH PETRUKHIN} (1939-2014)

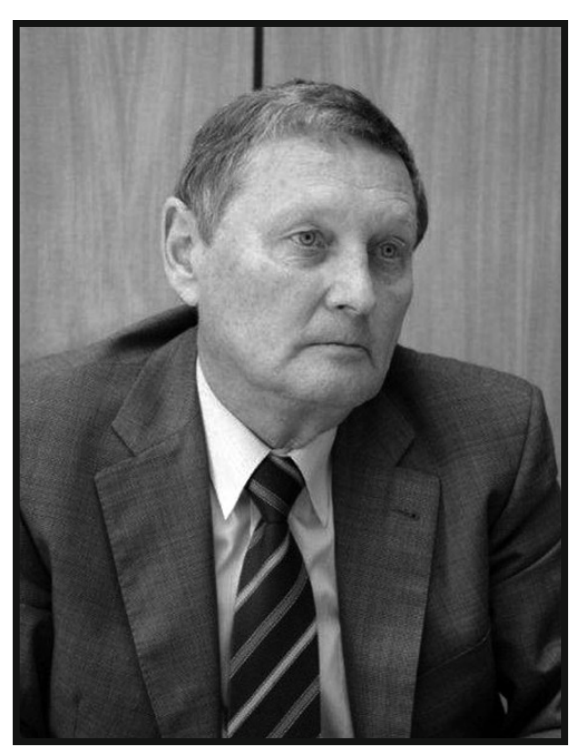

The Scientific-Research Center Stroitel'stvo is suffering an irreplaceable loss. 75-year-old Valerii Petrovich Petrukhin Director of the N. M. Gersevanov Scientific-Research Institute of Foundations and Underground Structures, Doctor of Technical Sciences, Professor, Honorary Scientist of the Russian Federation, leading specialist in the field of geotechnics, recipient of the State Prize of the USSR, recipient of the Government Prize of the Russian Federation in the field of sciences and engineering, outstanding expert in the field of soil mechanics, foundation engineering, and underground construction has passed away.

Dr. Petrukhin was born in 1939 in Tbilisi, and graduated from the Lomonosov Moscow State University in 1962. Working in the Scientific-Research Institute of Foundations and Underground Structures since 1964, he had traveled a path from junior scientific co-worker to director of the institute.

He developed methods for analysis and design of beds and foundations of buildings and structures on saline soils, and participated in lunar-soil investigations. In the past 10 years, he headed the most critical studies involving design and scientific-technical accompaniment of the construction and reconstruction of unique objects, such as the P. I. Chaikovskii Conservatory, the A. S. Pushkin Museum, "Lakhta" Center, "Moscow-City", olympic objects in Sochi, and stadiums in Moscow, Saint Petersburg, Rostov-na-Donu, Nizhne Novgorod, and other cities.

Basic regulatory documents for governing design and construction of foundations of buildings and underground structures in the Russian Federation have been developed under his guidance and with his direct participation. He was a member of the editorial staff, author, and critic of our journal.

It is difficult to overstate what Mr. Petrukhin had done for the institute and the entire staff of the Scientific-Research Institute of Foundations and Underground Structures. He had always been a sage, virile, cheerful and just person.

A vivid memory of Mr. Petrukhin will always remain in the hearts of those who knew him.

The editorial office and editorial staff of our journal and the RSSMGE, and also specialists in the field of foundation engineering express deep condolence to the family, friends, and colleagues of Mr. Petrukhin.

Translated from Osnovaniya, Fundamenty i Mekhanika Gruntov, No. 3, p. 32, May-June, 2014. 